\title{
Развитие музейного дела в Республике Тыва: история и современность
}

\author{
Каадыр-оол А. Бичелдей, Солангы Ю. Чыргалан, Оттук Ю. Игрит \\ Национальный музей им. Алдан-Маадыр Республики Тыва, Российская Федерация,
}

Хулербен К. Кадыг-оол

Нацииоальный музей им. Алдан-Маадыр Республики Тыва; Тувинский государственный университет,

Российская Федерация
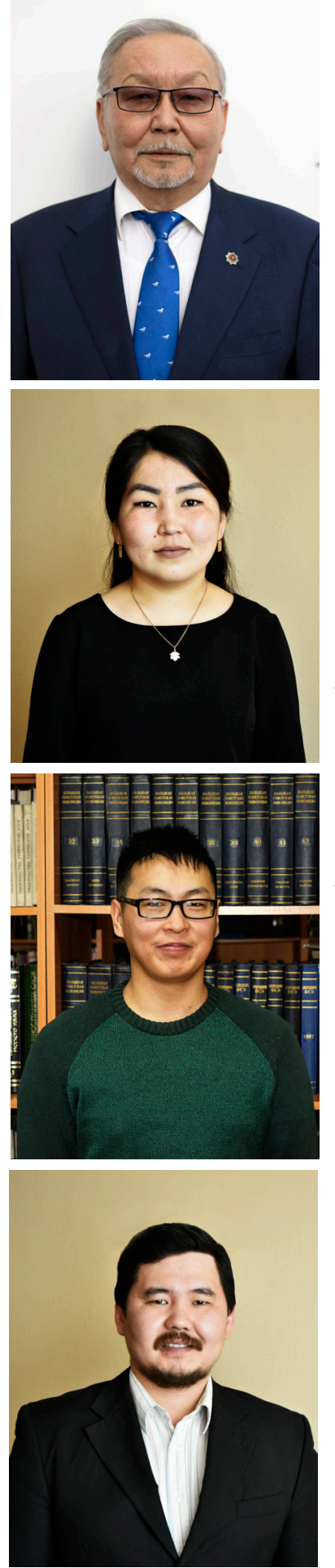

90-летний юбилей Национального музея им. Алдан-Маадыр Республики Тыва - повод подвести определенные итоги в области музейного дела Тувы. Музей сегодня является культурным и научным центром республики, играет важную роль в сохранении культуры, в развитии воспитания и пр. В статье анализируется история развития музейного дела в Туве, формулируются современные проблемы и новые вызовы на фоне глобальных трендов, которые происходят с музеями мира.

Даны количественные характеристики на сегодня: число сотрудников музея (в том числе по разным категориям), показатели фондов музея. Имеется 7 филиалов. Отмечено, что тувинский музей по фондам является одним из самых богатых в Южной Сибири. Проанализированы виды и показатели научно-исследовательской деятельности коллектива. Отмечены организационные проблемы. Перспективным направлением работы названо археологическое в сотрудничестве с другими научными учреждениями.

Представлены формы работы с посетителями. Возможности расширения и улучшения работы показаны на примере филиала - музея истории политических репрессий. Сформулирована задача полной реэкспозиции в залах до 2021 года, которая рассматривается как творческая. Насущная задача - использование современных технологий, которая сейчас решается, но в минимальном виде. Важно соблюсти баланс с привычными формами работы и сохранить статус ведущего культурного и просветительского учреждения Тувы.

Международное сотрудничество музея сегодня развивается в двух основных направлениях: обмен выставками с зарубежными музеями и предоставление своей площади для международных мероприятий.

Ключевые слова: Национальный музей Республики Тыва; Тува; тувинская культура; культурное наследие; музееведение

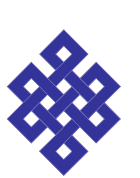

\section{Для цитирования:}

Бичелдей К. А., Чыргалан С. Ю., Иргит О. О., Кадыг-оол Х. К. Развитие музейного дела в Республике Тыва: история и современность [Электронный ресурс] // Новые исследования Тувы. 2019, № 2. URL: https://nit.tuva.asia/nit/article/view/841 (дата обращения: дд.мм.гг.). DOI: 10.25178/nit.2019.2.1

Бичелдей Каадыр-оол Алексеевич - доктор филологических наук, директор Национального музея им. Алдан-Маадыр Республики Тыва. Адрес: 667000, Россия, г. Кызыл, ул. Титова, д. 30. Тел.: +7 (394-22) 2-28-04. Эл. адрес: bka.hural@mail.ru ORCID ID: 0000-0002-6754-7794

Чыргалан Солангы Юрьевна - научный сотрудник отдела истории Национального музея им. АлданМаадыр Республики Тыва. Адрес: 667000, Россия, г. Кызыл, ул. Титова, д. 30. Тел.: +7 (394-22) 2-28-04. Эл. адрес: solangy.tchyrgalan@yandex.ru ORCID ID: 0000-0002-4067-120X

Иргит Оттук Юрьевич - научный сотрудник филиала политических репрессий Национального музея им. Алдан-Маадыр Республики Тыва. Адрес: 667000, Россия, г. Кызыл, ул. Титова, д. 30. Тел.: +7 (394-22) 2-28-04. Эл. адрес: irgit_06x@mail.ru ORCID ID : 0000-0002-4026-8373

Кадыг-оол Хулербен Кок-оолович - кандидат философских наук, магистр математики, заместитель директора по научной работе Национального музея им. Алдан-Маадыр Республики Тыва; старший преподаватель кафедры алгебры и геометрии Тувинского государственного университета. Адрес: 667000, Россия, г. Кызыл, ул. Титова, д. 30. Тел.: +7 (394-22) 2-28-04. Эл. адрес: hoolerben@yandex.ru ORCID ID: 0000-0002-9162-4470

Bicheldey Kaadyr-ool Alexeevich, Doctor of Philology, Director, Aldan-Maadyr National Museum of the Republic of Tuva; Member, Russian Academy of Natural Sciences; Russian Academy of Social Sciences. Postal address: 30 Titov St., 667000 Kyzyl, Russian Federation. Tel.: +7 (394-22) 2-28-04. E-mail: bka.hural@mail.ru Chyrgalan Solangy Yuryevna, Research Fellow, Aldan-Maadyr National Museum of the Republic of Tuva. Postal address: 30 Titov St., 667000 Kyzyl, Russian Federation. Tel.:+7 (394-22) 2-28-04. E-mail: solangy. tchyrgalan@yandex.ru

Irghit Ottuk Yuryevich, Research Fellow, Aldan-Maadyr National Museum of the Republic of Tuva. Postal address: 30 Titov St., 667000 Kyzyl, Russian Federation. Tel.: +7 (394-22) 2-28-04. E-mail: irgit_06x@mail.ru Kadyg-ool Khulerben Kok-oolovich, Candidate of Philosophy, Master of Mathematics, Deputy Director for Research, Aldan-Maadyr National Museum of the Republic of Tuva; Senior Lecturer, Department of Algebra and Geometry, Tuvan State University. Postal address: 30 Titov St., 667000 Kyzyl, Russian Federation. Tel.: +7 (394-22) 2-28-04. E-mail: hoolerben@yandex.ru 


\title{
Development of Museum Affairs in the Republic of Tuva: history and present time
}

\author{
Kaadyr-ool A. Bicheldey, Solangy Yu. Chyrgalan, Ottuk Yu. Irgit \\ Aldan-Maadyr National Museum of the Republic of Tuva, Russian Federation, \\ Khulerben K. Kadyg-ool \\ Aldan-Maadyr National Museum of the Republic of Tuva; Tuvan State University, \\ Russian Federation
}

\begin{abstract}
90th anniversary of the Aldan-Maadyr National Museum of the Republic of Tuva provides an opportunity to take stock of museum work and its development in the republic. The museum currently functions as a cultural and research center of the region, playing a significant role in education, as well as preservation of culture and other spheres. The article examines the history of museum work in Tuva, also focusing on contemporary issues and new challenges offset by global trends in the museum industry.

Provided are some quantitative indicators of the current state of affairs, such as the overall number of museum workers (classified by category), including all of its 7 branch offices. By the size of its collections, National Museum of Tuva is one of the largest in South Siberia. The authors assess the types and outcomes of research done by the museum staff, and also describe the problems to be solved. Archaeological work in collaboration with other research institutions is said to have a lot of potential.

The most important priority at the moment lies in collaborating with other research institutions. The article also looks at how museums can work with their visitors. Methods of expanding and improving this work are exemplified by the case study of the Museum of political repressions, a constituent part of the National Museum. By 2021, all museum spaces have to undergo an exposition upgrade - a task which can only be seen as a creative one. Another important challenge is the adoption of contemporary technologies, which so far has had only a minimal solution. In doing so, a balance should be found between innovative and traditional forms of museum work. The status of the leading cultural institution of Tuva, which the museum currently has, should never be threatened.

International cooperation at the museum is now developing along two major lines - exchanging exhibition projects with foreign partner museum and providing venues for international events.
\end{abstract}

Keywords: National Museum of the Republic of Tuva; Tuva; Tuvan culture; cultural heritage; museum studies

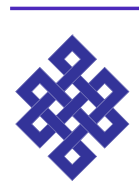

For citation:

Bicheldey K. A., Chyrgalan S. Yu., Irgit O. Yu. and Kadyg-ool Kh. K. Development of Museum Affairs in the Republic of Tuva: history and present time. The New Research of Tuva. 2019, no. 2. URL: https://nit.tuva.asia/nit/article/view/841 (access date ... ). DOI: 10.25178/nit.2019.2.1

\section{Введение}

Национальный музей имени Алдан-Маадыр Республики Тыва (далее - НМ РТ) в 2019 г. празднует 90 лет со дня создания. С 13 мая 1929 г. также начинается официальная история музейного дела Тувы. За это время музей добился значительных успехов. Сформировались уникальные коллекции, которые стали широко известны за пределами республики. Существенно изменился подход к музейному делу как к профессиональной деятельности. В стенах НМ РТ выросли ученые-исследователи республиканского, общероссийского и мирового уровней, само учреждение играет важную роль в научной, культурной, общественной жизни Тувы. В 2008 г. музей обрел новое современное здание, которое открыло новые возможности для развития музейного дела в целом и стало одним из символов культуры Тувы.

Тем не менее, было бы наивно утверждать, что за фасадом перечисленных достижений не осталось серьезных вопросов разного характера. Особенностью НМ РТ является то, что в одной организации сконцентрированы все направления музейного дела: от естественно-научных исследований до организации и кураторства музеев в образовательных организациях и различных ведомствах Тувы. Как правило, в регионах с более развитой соответствующей системой имеются несколько музеев, включая частные, которые работают в более специализированных направлениях. В Туве же координация республиканских усилий в этом направлении ведется именно в одном музее.

90-летие для музея - хороший повод для того, чтобы подвести ряд итогов, рассмотреть проблемы и очертить перспективы развития. В данной статье мы поразмышляем над почти вековой историей музейного дела Тувы, сквозь призму истории становления и развития главного музея республики, а также проанализируем новые вызовы, стоящие перед ним. 


\section{Музейное дело}

Прежде всего определимся с основными терминами.

Мы говорим о музейном деле, что подразумевает не только научные изыскания, но и всю деятельность, связанную с работой музеев. До сих пор отсутствует устоявшееся определение того, что есть музейное дело. Его нет и в соответствующем Федеральном законе от 26.05.1996 № 54-ФЗ «О Музейном фонде Российской Федерации и музеях в Российской Федерации» (Федеральный закон «О Музейном фонде ..., Электр. ресурс). Тем не менее, исследователи отмечают, что музейное дело представляет собой особую форму культурной деятельности, в которой выделяются теоретический и практический уровни (Музейное дело России, 2003). В Российской музейной энциклопедии приводится следующее определение: «Музейное дело, область культурной деятельности, нацеленной на обеспечение функционирования музея как учреждения и выполнения им социальных функций музея. Становление М. д. неразрывно связано с формированием направлений музейной деятельности и музейных профессий. В 20 в. М. д. становится объектом культурной политики государства. В разных странах имеет свою специфику» (Музейное дело, Электр. ресурс) ${ }^{1}$.

Собственно термин «музей» в Федеральном законе от 26.05.1996 № 54-ФЗ трактуется как «некоммерческое учреждение культуры, созданное собственником для хранения, изучения и публичного представления музейных предметов и музейных коллекций, включенных в состав Музейного фонда Российской Федерации, а также для достижения иных целей, определенных настоящим Федеральным законом» (Федеральный закон «О Музейном фонде ..., Электр. ресурс)..

Интересно сравнение с тем, что понимают под «музеем» в других странах. К примеру, Американская ассоциация музеев определяет музей в XX в. как «организованный институт, работающий на постоянной основе, деятельность которого не подразумевает получения прибыли, по сущности направлен на достижение образовательных или эстетических целей, имеющий профессиональный штат сотрудников, данный институт владеет материальными объектами или использует их, хранит их, а также выставляет на общественное обозрение по некоторому графику» (Alexander P., Alexander M., 2008: 2).

В 1995 г. Международный комитет музеев (ИКОМ) определил музей как «некоммерческий, действующий на постоянной основе институт, предназначенный для служения обществу и его развития, а также открытый для широких слоев населения, который приобретает, хранит, изучает, выстраивает коммуникации и делает экспозиции материальных объектов, принадлежащих людям или из их среды обитания, в целях изучения, образования и развлечения» (там же). Видно, что в целом все приведенные определения подчеркивают некоммерческий характер музеев и предполагают примерно одинаковые цели.

В 2015 г. вышел очередной номер официального журнала ИКОМ, темой которого стали новые тенденции в музейном деле. Опираясь на обзорную статью президента этой организации Ф. Мэрэсса (Маiresse, 2015: 15), мы выделим следующие основные тренды:

- трансформация экономики и вытекающая отсюда трансформация музейной деятельности в сфере комплектования фондов, прежде всего шедевров живописи, фактически, музеи становятся полноправными участниками рыночных отношений в рамках неолиберальной экономики;

- развитие цифровых технологий, появление т. н. «кибермузеологии», влияние Интернета и социальных сетей на деятельность музеев;

- изменение отношений и ролей в схеме «музей-посетитель».

Так, музеи понимаются нашими зарубежными коллегами не просто как узкоспециализированные учреждения, а как социальные институты, некоммерческие по своему характеру, где важна деятельность профессионалов. И эти социальные институты сегодня испытывают значительные трансформации в связи с широкими социальными и культурными изменениями всего мира.

Мы принимаем данную трактовку музея, а также соответствующего ей музейного дела, и полагаем, что музейное дело в Республике Тыва, будучи важным элементом культуры и общества в целом, претерпевает сегодня существенные изменения, которые требуют осмысления. Результатом этого анализа должны стать новые подходы к развитию, которые позволят, с одной стороны, сохранить классические функции музея, с другой стороны более органично интегрировать в свою деятельность современные тенденции.

\footnotetext{
${ }^{1}$ В уже упомянутой коллективной монографии «Музейное дело России» предлагается наравне с данным термином говорить о «музейном мире», правда, также без четкого определения (Музейное дело России, 2003: 3).
} 


\section{Из истории развития музейного дела Тувы}

Мировая история музейного дела уходит корнями в древние времена. Исследования истории появления естественно-научных коллекций приводят к собраниям скальпов горилл в Карфагене или рогов скифских быков, которые Александр Македонский пожертвовал храму в Дельфах (Hagen, 1876: 81). Если музейное дело рассматривать таким образом, то возникает вопрос о том, было ли музейное дело на территории Тувы до 13 мая 1929 г. - официальной даты основания нынешнего НМ РТ. Мы считаем, что было.

Например, по мнению авторов книги «Музеи в движении», в Древней Греции и Древнем Риме прототипами музеев можно считать богато обставленные храмы, посвященные разным богам (Alexander P., Alexander M., 2008: 4). Помимо того, что собрания артефактов в них предназначались для религиозных целей, они представляют собой организованные коллекции, предназначенные для хранения, определенного использования, передаче последующим поколениям. Согласно такому пониманию, буддийские храмы Урянхайского края также можно рассматривать как прототипы музеев. Частные коллекции состоятельных лиц, воинов, знати, аристократии также можно рассматривать подобным образом (там же: 7), что позволяет говорить и о деятельности тувинской знати, скажем, XVIII и XIX вв., которые в своих юртах хранили замечательные образцы утвари, мебели, одежды, разных принадлежностей и т. д. Не все коллекции сохранились, какие-то были уничтожены, утеряны. Но известна, например, судьба имущества чиновника Идан-Сюрюна, которая была конфискована государством в 1928 г. и стала основой для будущего музейного фонда (Дыртык-оол, 2009b: 9).

Данное событие оказало существенное влияние на принятие решения о создании музея в Туве. Сама же официальная история музейного дела начинается, как уже было сказано выше, 13 мая 1929 г.

В целом, научную литературу, посвященную НМ РТ, можно условно разделить на три группы: исследования истории музея; публикации о деятельности музея (сохранение культурного наследия, описание коллекций, экспозиций и т. д.); работы по теоретическим аспектам (музееведение или музеология).

Первая группа. Наиболее ценными трудами по истории НМ РТ являются работы А. О.Дыртык-оол (Дыртык-оол, 2009ab, 2013). Например, автором приведены основные этапы развития музейного дела в Туве. Отмечается, что заметные улучшения в работе НМ РТ были связаны с именами выдающихся личностей: В. П. Ермолаева, Н. М. Богатырева, Д. Б. Данзын-оола, С. И. Вайнштейна, М. Б. Кенин-Лопсана, К. И. Черненко и др. Благодаря их прорывным достижениям разные отрасли музейного дела Тувы (научные исследования, формирование фондов, культурно-просветительская работа, экспозиционная деятельность и др.) сложились в единую систему.

В целом, историю музейного дела в Туве, по нашему мнению, можно рассматривать по следующим этапам:

- предыстория;

- зарождение в качестве особой профессиональной сферы;

- развитие в советское время;

- развитие в 1990-2008 гг.

- развитие с 2008 г. по настоящее время.

Предыстория музейного дела в Туве еще нуждается в исследованиях, поскольку не все ее страницы освещены достаточно. Отдельные эпизоды можно найти в воспоминаниях, в художественной литературе. Например, история уничтожения коллекций описывается в романе С. Тока «Слово арата»:

«И вот уже сотня всадников помчалась в Аксы-Барлык и Алдын-Булак. Араты с ходу набрасывали арканы на ограду, на купола монастырских строений и, гикая, нахлестывая коней, тянули арканы на себя. В клубах пыли рушилось хуре. В воздухе летали разорванные в клочья молитвенные книги.

Кто-то проткнул барабан. Трещали по швам занавески» (Тока, 1973: 389).

Зарождение музейного дела в республике тесно связано с деятельностью В.П.Ермолаева,легендарного первого директора краеведческого музея. Ему удалось собрать заметную коллекцию этнографических предметов, не рискуя быть обвиненным в симпатиях к феодалам или «старорежимному», «отсталому» образу жизни аратов. Он же стал первым профессиональным фотографом Тувы, который на протяжении 45 лет систематически делал снимки людей, природы и т. д. (Дыртык-оол, 2013: 11). Ермолаев был многосторонним человеком. Например, М. Б. Кенин-Лопсан считает его одним из основателем русскоязычной литературы Тувы (Кенин-Лопсан, 2013: 8).

В 1933 г. в фонде тувинского музея насчитывалось 4669 единиц хранения. 
В советское время музейное дело Тувы обрело основную материальную базу, было поставлено на профессиональную основу. Музей развивался, в его деятельности сложились определенные традиции, что было отмечено на всесоюзном уровне ${ }^{1}$ (Дыртык-оол, 2009b: 14). Самым важным в становлении музея мы считаем формирование коллектива заинтересованных и глубоко преданных делу специалистов, многие из которых посвятили музею всю свою профессиональную жизнь. Их энтузиазм, активность, авторитет помогали формировать фонды. Население, доверявшее специалистам, несло и до сих пор продолжает нести в музей ценные предметы из семейных архивов, причем на безвозмездной основе. В этой связи необходимо отметить глубокую заинтересованность и особый талант М. Б. Кенин-Лопсана, который много выезжал в районы, встречался с людьми, вел разъяснительную работу (фото 1).

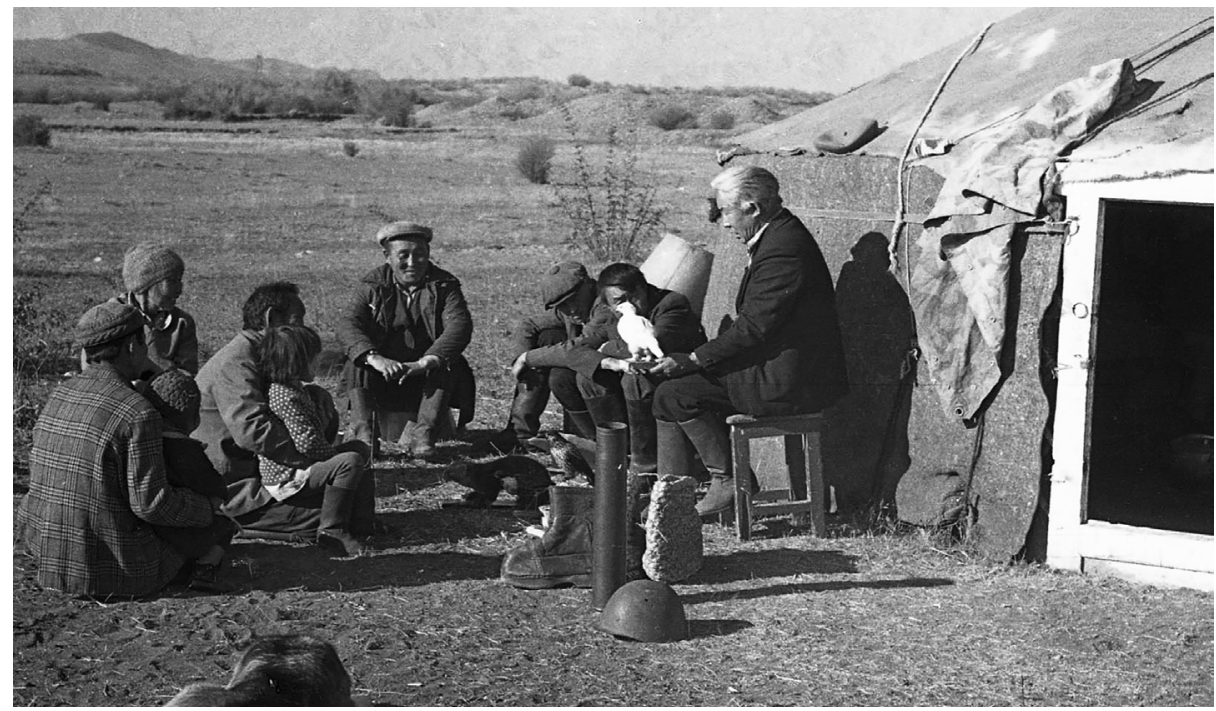

Фото 1. М. Б. Кенин-Лопсан рассказывает на выезде к чабанам об экспонате. Село Чыраа-Бажы, Дзун-Хемчикский район, 1975 г. Автор фото неизвестен. Из фондов НМ РТ.

Photo 1 M.B. Kenin-Lopsan explaining an exhibit to herders. Village Chyraa-Bazhy, Dzun-Khemchinsky rayon, 1975. Photographer unknown. Courtesy of National Museum, Republic of Tuva

В постсоветское время, когда многие отрасли культуры, да и вообще положение дел в республике как таковое, находились в глубоком и затяжном кризисе, именно энтузиазм работников музея позволял учреждению не просто выживать, но и реализовывать новые проекты (Дыртык-оол, Мартынов, 2019: Электр. ресурс).

Последние годы принесли одновременно и новые возможности, и определяют новые задачи. Например, в 1993 г. в музее был создан отдел религии, в том же году открылась выставка «Шаманы в Центре Азии. Мифологическое наследие тувинцев». Годом позже был создан филиал музея, основной темой которого стали политические репрессии (Дыртык-оол, 2009b: 15-16).

2008 год стал особо важным для музея, поскольку произошел ряд важных событий, сформировавших современный облик НМ РТ. Во-первых, было сдано в эксплуатацию здание музея, строительство которого началось еще в далеком 1991 г. Музей переехал в красивый комплекс по ул. Титова, д. 30. Во-вторых, в этом же году произошло долгожданное открытие выставки знаменитого золота скифов из кургана Аржаан-II. Само здание музея и прилегающая к нему территория стали одной из главных достопримечательностей города, а постоянная экспозиция в «Золотом зале» принесла НМ РТ мировую славу. Таким образом, с 2008 г. идет современная летопись музейного дела Тувы.

Вторая группа. Среди публикаций по отдельным вопросам деятельности музея необходимо отметить оригинальные работы М. Б. Кенин-Лопсана. Необходимо оговорить, что в целом научное наследие Монгуша Бораховича, разумеется, выходит за рамки музееведения. Вместе с тем, некоторые из его работ посвящены непосредственно музейному делу Тувы или предметам из коллекций НМ РТ (Кенин-Лопсан, 2009, 2013). Широко известны его труды по традиционной культуре тувинцев (Кенин-Лопсан, 2006).

${ }^{1}$ Например, в 1956 г. по результатам Всероссийского конкурса по содержанию экспозиций Тувинский областной музей был признан одним из лучших и награжден дипломом I степени. 
Особняком в трудах нашего выдающегося исследователя стоят работы по шаманской тематике (КенинЛопсан, 1987, 2007, 2008 и др.). В целом, в данном разделе можно отметить целую россыпь интересных статей разных авторов.

Например, в продолжение темы шаманизма и соответствующих коллекций отметим работу А. М.Допай, посвященной собранию шаманских предметов (Допай, 2013). Тувинскому искусству посвящена одна из работ ветерана музейного дела А. С. Хертека (Хертек, 2006). Проблемам реставрации посвящена работа главного хранителя НМ РТ и крупнейшего специалиста по традиционной одежде тувинцев Р. Б. Ховалыг (Ховалыг, 2013). Некоторые темы буддийской коллекции раскрываются в статьях Р. П. Сумба, главного специалиста по буддологии НМ РТ (Сумба, 2013). Заслуживает внимания работа по этнографическим колекциям музея, автором которой является У. Б. Нурзат, один из опытнейших специалистов по фондам (Нурзат, 2013).

Третья группа литературы (музееведение, музеология) является до сих пор самой незначительной. Пожалуй, отметим лишь ставшее незаменимым для каждого начинающего музейного работника Тувы методическое пособие А.О.Дыртык-оол «Экспозиционно-выставочная работа в музее» (Дыртык-оол, 2014).

На конец 2018 г. в НМ РТ работало 138 человек, из них 75 - специалисты, включая научных сотрудников. Только 8 чел. имеют профессиональное образование в области музейного дела. Подобное соотношение ставит задачи повышения квалификации, которые музей решает. В 2018 г. 21 специалист НМ РТ прошел обучение по программе «Музейное дело». В музее числятся 1 доктор наук и 4 кандидата наук, то есть 6,9\% сотрудников имеют ученые степени. В настоящее время к защите кандидатской диссертации готовятся трое научных сотрудников (по историческим специальностям): С. Ю. Чырглан, О. Ю. Иргит, М. О. Дыртык-оол. В аспирантуре обучаются два человека: С. А. Лакпаева, Р. Р. Сангы-Бадра. Таким образом, имеется перспектива в обозримом будущем заметного пополнения рядов остепененных научных сотрудников.

Согласно внутреннему годовому отчету за 2018 г., фонды НМ РТ насчитывают 154815 музейных предметов, из них: 119156 единиц основного фонда и 35659 единиц научно-вспомогательных материалов. Для сравнения: фонд Хакасского национального краеведческого музея имени Л. Р. Кызласова составляет более 120 тысяч экспонатов (Хакасский национальный...: Электр. ресурс), фонд Национального музея имени А. В. Анохина (Республика Алтай) - более 60 тысяч единиц хранения (История музея: Электр. ресурс). То есть тувинский музей один из самых богатых в Южной Сибири.

Музей имеет 7 филиалов. Последний был открыт в 2018 г. Это музей-заповедник (под открытым небом) в местечке Белдир-Кежии Улуг-Хемского района Республики Тыва. Изначально это был проект Тувинской региональной общественной организации «Мир тувинцев». Предполагалось, что будет создан единый комплекс. На его территории с 2014 г. были возведены объекты, которые связаны с буддизмом, тенгрианством, историей Тувы ${ }^{1}$.

\section{Научные исследования в музее Тувы}

Научно-исследовательская деятельность является одним из ведущих направлений деятельности НМ PT. В музее на сегодняшний день имеется 4 научных отдела: истории; археологии; культуры, искусства, религии; краеведения и туризма. Наряду с научными сотрудниками научно-исследовательской работой в музее занимаются хранители фондов, экскурсоводы, специалисты. Исследовательская деятельность музея ведется в двух основных направлениях: изучение всего музейного собрания НМ РТ и исследования, связанные в целом с музееведением.

Изучение музейного собрания является базовой основой для фундаментальных и прикладных исследований. Научным описанием музейных предметов, являющимся одним из видов исследовательской работы, занимаются все научные сотрудники НМ РТ. Кроме того, материалы фондов НМ РТ используются в качестве источниковой базы для научных работ сотрудников, занимающихся различными темами.

Научная деятельность музея реализуется в стандартных формах: научно-практические конференции, организованные музеем; апробация научных трудов сотрудников в научно-практических конференциях, организованных другими учреждениями, и публикация научных работ в виде монографий и статей в периодических изданиях.

\footnotetext{
${ }^{1}$ Более подробно с проектом можно ознакомиться на сайте ТРОО «Мир тувинцев» (Проект БЕЪЛДИР-КЕЪЖИИ, Электр.
} ресурс). 
Согласно статистическим данным из отчетов НМ РТ, за 2014-2018 гг. музей организовал 24 научных мероприятия, в том числе 5 научно-практических конференций (2014 г. -1 ; 2015 г. - 1; 2016 г. - 1; 2017 г. - 2), 9 круглых столов (2014 г. - 2; 2015 г. - 1; 2016 г. - 1; 2017 г. - 1; 2018 г. - 4). Также музей выступил соорганизатором одной научно-практической конференции (2015 г.), одного научного заседания (2014 г.); 3 круглых столов (2015 г. - 1, 2017 г. - 2). Музей оказал содействие в проведении одной республиканской конференции (2018 г.) и 2 круглых столов (2018 г.). Динамика показателей проведенных мероприятий по годам (2014 г. - 4, 2015 г. - 4, 2016 г. - 2, 2017г. - 7, 2018 г. - 7) свидетельствует о том, что научная жизнь музея с каждым годом становится активнее, расширяется. Необходимо отметить весьма важные сборники конференций, которые выходили ранее, в 2009 и 2013 гг. соответственно (Наследие народов ..., 2009; Первые республиканские ..., 2013).

Однако, если взглянуть на ситуацию с другого ракурса, становится очевидно, что речь идет скорее о развитии научно-организационной формы без тесной связи с научно-исследовательской и публикационной форм.

Одной из главных сложностей в научном направлении НМ РТ является то, что музей не является научной организацией с точки зрения своего официального статуса, а является учреждением культуры. Соответственно на него не распространяется действие Указа Президента Российской Федерации № 597 от 7 мая 2012 г. «О мероприятиях по реализации государственной социальной политики» (Указ Президента ..., 2012: Электр. ресурс), то есть не имеется оснований для повышения заработной платы по результатам научной деятельности.

Это сказывается на публикационной активности. В 2018 г. сотрудники опубликовали 44 работы, из них статьи в журналах списка ВАК - 5 единиц, индексируемых в РИНЦ -23 единицы. Для сравнения, в 2017 г. всего было 33 публикации, из них ВАК - 2, РИНЦ - 6. В 2016 г., к примеру, «ваковских» статей и вовсе не было. До сих пор Национальный музей Тувы не зарегистрирован в РИНЦ. И до 2019 г. у его сотрудников не было ни одной публикации в журналах, индексируемых в международных базах научной индексации, в т. ч. в Scopus и Web of Sciences.

Главную проблему можно обозначить следующим образом: научные сотрудники НМ РТ часто видят свою роль в музее в исключительно узкоспециальном ракурсе, а именно - в организации выставок (разных типов), составлении научных описаний экспонатов, чтении лекций, проведении экскурсий. Примерно так же обстоят дела в части научно-фондовой работы. Хранители, которые приравнены к научным сотрудникам НМ РТ, как правило, видят свои задачи преимущественно в обновлении данных каталога, составлении описей и т. д., т. е. фактически, речь идет о, скорее, технической, ежедневной, рутинной работе. Последняя, разумеется, также крайне важна, но не является исчерпывающей.

Подобное положение дел негативно сказывается на всех остальных направлениях деятельности НМ РТ. Ценные и редкие экспонаты оказываются «забытыми» в подвалах музея, поскольку о них не пишут статей, по ним не составляют каталоги. И вопрос в данном случае стоит не только в увеличении известности музея и его коллекций, а гораздо глубже. Фактически, речь идет о сохранении и популяризации культурного наследия. Без современной системы научной работы музей становится в некотором смысле обычным складом артефактов.

Большие надежды сейчас мы связываем с археологическим направлением научных исследований как самих сотрудников музея, так и коллег из научных учреждений, с которыми у НМ РТ традиционные многолетние связи. На сегодняшний день идет формирование отдельного отряда археологов музея, которые будут принимать участие в раскопках в составе крупных экспедиций. Два научных сотрудника отдела археологии - К. М. Монгуш и М. А. Монгуш - получили право на открытый лист, т. е. на проведение археологической разведки. Летом 2019 г. оба будут работать в составе международной группы археологов на раскопках кургана «Туннуг» в «Долине Царей» Пий-Хемского района Республики Тыва.

Также в наших планах большая работа с архивами, сданными в фонды музея. Например, запланирована публикация большого архива археологических отчетов С. И. Вайнштейна.

Возможно, ситуацию могло бы преломить внесение научных сотрудников НМ РТ в соответствующий республиканский реестр, чтобы таким образом они смогли бы подпадать под действие упоминавшегося Указа Президента РФ. Одной из сложностей является то, что до сих пор не имеется четких критериев, согласно которым то или иное учреждение может обладать статусом «научно-исследовательского института» или «научно-исследовательского центра» ${ }^{1}$. Вопрос признания специалистов Тувы научными

${ }^{1}$ В 2018 г. мы делали запрос в Министерство образования и науки Российской Федерации по поводу данных критериев, в ответном письме нам разъяснили, что в законодательстве РФ не закреплены понятия «научно-исследовательский институт» и «научно-исследовательский центр». 
сотрудниками, которые уже подпадают под действие упоминаемого Указа, решается Правительством Республики Тыва. В результате данного шага существенно улучшится финансовое положение указанной категории работников, в связи с чем можно было бы ожидать увеличение количества опубликованных научных трудов.

Необходимы и иные способы стимулирования научных исследований, не связанные исключительно с финансовыми механизмами. В 2018 г. в качестве своеобразного эксперимента в музее был введен дополнительный, вспомогательный критерий эффективности - индивидуальный рейтинг научного сотрудника, подразумевающий комплексный анализ достижений. По итогам 2018 г. на его основе было осуществлено небольшое денежное премирование для тройки лидеров. Также был разработан новый формат индивидуального плана.

\section{Работа с посетителями музея}

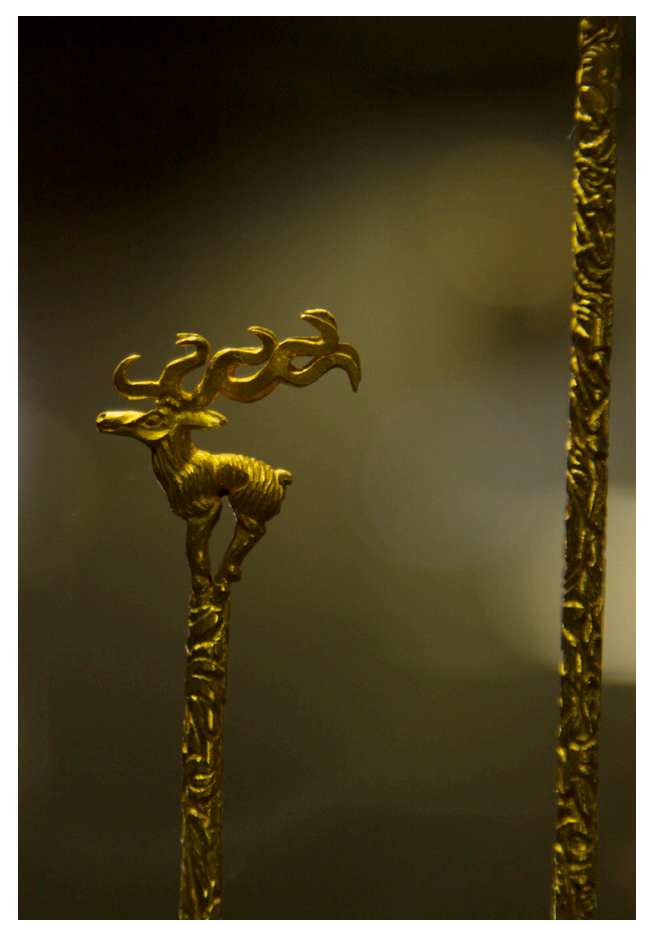

В настоящее время основные экспозиции музея размещены в 16 залах на двух этажах в главном здании по адресу г. Кызыл, ул. Титова, д. 30. Отметим, что настоящая структура размещенных выставок нас не удовлетворяет и соответственно мы ставим задачу полной реэкспозиции в залах НМ РТ до 2021 года.

Это связано с тем, что из единого полотна «выпали» целые фрагменты истории. Например, в постоянной экспозиции нет материалов по эпохе хунну, средних веков. Парадоксально, но музей, который носит имя Алдан-Маадыр ${ }^{1}$, не имеет хотя бы небольшого «куска» экспозиции, который бы рассказывал посетителям об этой странице нашей истории. Филиал в одноименном селе является довольно удаленным (примерно в 250 км от г. Кызыла) и не доступен для массового посещения.

Также можно отметить, что залы природы «раскиданы» по всему 2 этажу (в 1, 2 и 7 залах). Исторические или этнографические залы идут вперемежку с залами искусства, религии и т. д.

Очевидно, что подобная ситуация сложилась в результате спешки при заезде в новое здание в 2008 г., когда надо было скорее ввести здание в эксплуатацию, чтобы как можно скорее принять знаменитую коллекцию скифского золота (фото 2).

В связи с этим интересно отметить, что в старом здании по адресу г. Кызыл, ул. Ленина д. 7, несмотря на то, что оно было на порядок меньше нынешнего, экспозиция выглядела более логичной, структурированной. Таким образом, требуется определенное время для того, чтобы постоянная экспозиция в новом здании стала в большой степени завершенной, гармонично выстроенной.

Весьма важной задачей является не простой выбор уникальных экспонатов (их в фондах НМ РТ более чем достаточно) и какой-то их механической компоновке согласно заявленной теме того или иного зала, но более глубокое осмысление связи «экспонат - пространство - смысл» в целом. Условно говоря, для восточного человека более важны не стенки сосуда, но пустота, благодаря которой эти стенки существуют (Чжуан-Цзы, 1995: 236). Так и в НМ РТ, по нашему мнению, предстоит кропотливая работа по организации особой «пустоты» вокруг экспонатов. Тогда они получат больше смыслового пространства для выражения полноты своей семиотической нагрузки, наполняя пустоту вокруг себя эмоциями, переживаниями, мыслями, озарениями посетителя.

Интересной и творческой задачей представляется осмысление прилегающей территории к главному зданию НМ РТ. В старом здании как таковой прилегающей территории не было, если не считать внутренний дворик. Теперь главное здание НМ РТ и прилегающая территория занимают, фактически, целый квартал.

${ }^{1}$ Восстание шестидесяти богатырей (тув. - алдан маадыр) (1883-1885 гг.) - крупнейшее восстание тувинцев против китайской империи. Было жестоко подавлено, участники казнены. Музей был назван в честь восставших в 1942 г. 
Одной из первых попыток своеобразной экспозиционной эманации за пределы стен самого здания можно считать прошлогоднее оформление ниш по бокам четырех лестниц, которые раньше использовались под цветочные клумбы. В прошлом году там были установлены стелы древнетюркского периода (фото 3 u 4). Возможно, в дальнейшем подобные попытки превращения территории вокруг музея будут продолжены.
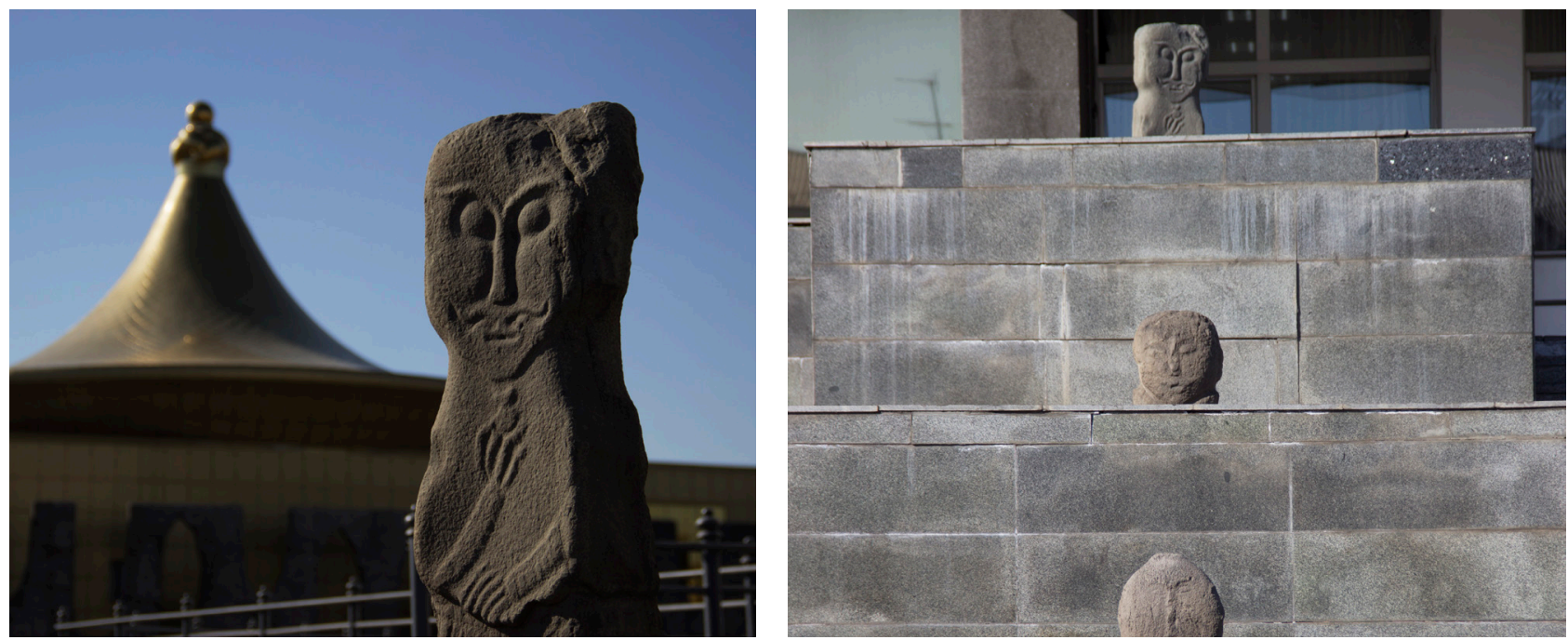

Фото 3 и 4. Скульптуры на боковых нишах лестницы НМ РТ, 2019 г. Фото А. Э. Мижита. Photos 3 \& 4 Statues in side niches of the National Museum stairway, 2019. Photo by A. E. Mizhit.

С неизбежностью встает вопрос использования современных технологий при экспонировании предметов. Развитие музейного дела в наше время показывает, что его основа - весьма гибкая (Alexander P., Alexander M., 2008: 10). Музеям необходимо ориентироваться на посетителей - активных пользователей всевозможных гаджетов. И использование в тувинском музее современных технологий также одна из насущных задач. В настоящее время данная деятельность только начинает получать свое развитие. Помимо использования виртуальных киосков, несложной мультимедийной техники, наш музей в 2019 г. получил «виртуальную копию», т. е. была создана 3D-модель всего помещения с залами. B самих экспозициях используется система QR-кодов, которая позволяет самостоятельно знакомиться с экспозициями.

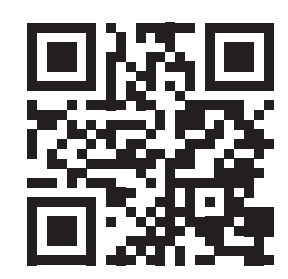

OR-код сайта музея. QR code of the Museum website.

Тем не менее, очевидно, что перечисленный арсенал технических решений своеобразный «минимальный» набор. Необходимо расширение ассортимента соответствующего инструментария. К примеру, во многих учреждениях культуры, в том числе в музеях, прекрасно зарекомендовала себя технология дополненной реальности. Также можно перенимать опыт учебных заведений, которые, например, давно используют интерактивные доски.

Наконец, отдельным пунктом идут технологии, которые полностью размывают границы традиционного музейного дела, например, связанные с досуговыми формами культуры. Нам кажется интересным опыт Музея естествознания в Лондоне (основанном в 1881 г.), в котором проводятся так называемые бесшумные дискотеки (silent disco). Посетителям раздаются специальные наушники, с помощью которых люди слушают музыку от специально нанятого диджея. Таким образом, дискотека проходит в тишине, создается необыкновенная атмосфера, когда разными цветами подсвечиваются, например, скелеты динозавров (Silent disco: Электр. ресурс). Билеты на такие дискотеки раскупаются очень быстро за много дней до назначенного.

В деятельности НМ РТ необходимо соблюсти баланс между его «всеядностью» (с неизбежностью ведущей в менее традиционные для музейного дела сферы досуга и развлечений) и более привычными формами работы. Тогда наш музей сможет быть ведущим культурным и просветительским учреждением региона. 


\section{Развитие музейного дела Тувы через филиалы, музеефикация современности}

На примере одного из филиалов НМ РТ - музея истории политических репрессий - рассмотрим возможности расширения и качественного улучшения музейного дела на местах.

Музей истории политических репрессий в Туве был открыт 14 февраля 1994 г. усилиями Тувинской правозащитной общественной организации «Мемориал» и старейшего сотрудника Национального музея М. Б. Кенин-Лопсана, по распоряжению Госкомитета Республики Тыва по управлению госимуществом и при поддержке министерства культуры Республики Тыва (Дыртык-оол, 2009а: 47). По информации В. С. Стафа, этот музей является первым государственным музеем по теме репрессий в России, так как другие музеи на базе ГУЛАГа и зданий НКВД, открытые до 1994 г., создавались по инициативе частных лиц (Стаф, 2018).

В настоящее время филиал активно развивается, постепенно налаживая связь с другими музеями по аналогичной теме. Приоритетной задачей филиала является реализация Концепции государственной политики по увековечиванию памяти жертв политических репрессий, утвержденной распоряжением Правительства РФ от 15 августа 2015 г. № 1561-р (Концепция ..., Электр. ресурс). Согласно этому документу, во всех субъектах России должны быть созданы условия для сохранения памяти жертв политических репрессий. Именно в этих целях 30 октября 2017 г. в Москве был открыт мемориальный комплекс «Стена скорби», при создании которого были использованы камни с мест расстрела жертв репрессий со всех субъектов России, в том числе из Республики Тыва. Камень, специально выбранный сотрудниками НМ РТ с местечка Агар-Элезин, где предположительно расстреляли семерых государственных деятелей ТНР, лежит под № 64 в столичном мемориальном комплексе.

В целях реализации упомянутой Концепции в 2015 г. Государственным музеем истории ГУЛАГа также была создана Ассоциация российских музеев памяти, которая объединяет все тематические музеи России, посвященные репрессиям, ГУЛАГу и НКВД (Об ассоциации, Электр. ресурс). Филиал тувинского музея вступил в ряды Ассоциации в ноябре 2017 г. Благодаря членству филиала в Ассоциации 30 марта 2018 г. в стенах Национального музея РТ была открыта выставка «Стена скорби», посвященная проекту создания одноименного мемориального комплекса. Во время открытия выставки был подписан специальный договор о сотрудничестве между Национальным музеем РТ и Музеем истории ГУЛАГа. Отметим, что благодаря соседству Тувы с Монголией, именно наш музей и его филиал рассматриваются коллегами из Музея истории ГУЛАГа, как мост для налаживания связей между музеями репрессий России и Монголии.

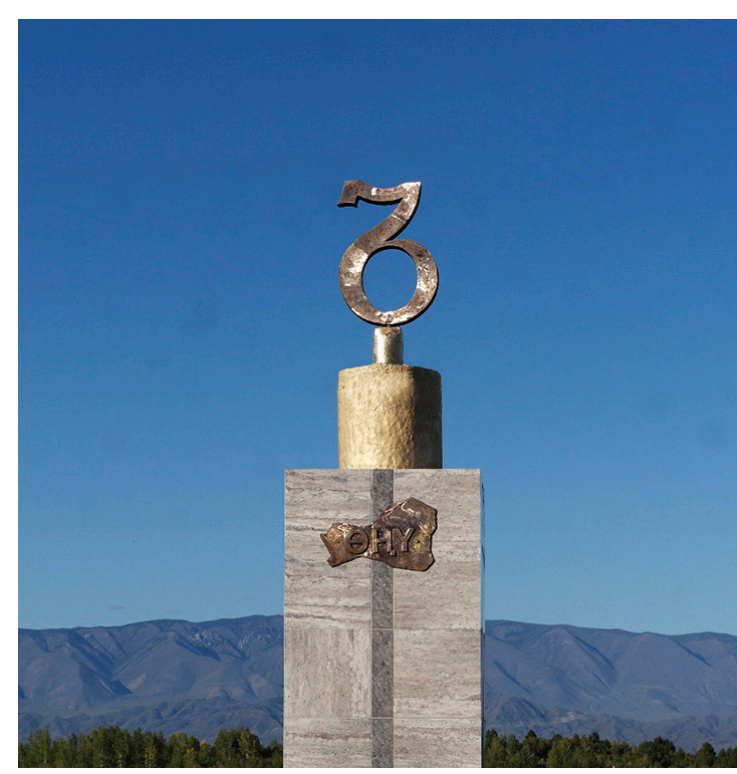

Фото 5. Памятник тувинскому языку на территории филиала НМ РТ «Белдир-Кежии».

Фото Х. К. Кадыг-оола, 2016 г.

Photo 5 Tuvan language monument at the Beldyr-Kezhii branch of the National museum, Republic of Tuva. Photo by Kh. K. Kadyg-ool, 2016.
В целях реализации Концепции и решения круглого стола «Дело девяти: особенности политических репрессий в Туве», который прошел в Национальном музее РТ 17 апреля 2018 г. (Круглый стол ..., 2018: Электр. ресурс), 30 октября 2018 г. в Кызыле был открыт мемориальный комплекс Оюну Танчаю Чырандай оглу - первому финансисту Тувы, инициатору создания тувинской национальной валюты «акша». Несмотря на выдающиеся заслуги в сфере политического и экономического строительства ТНР, в 1938 г. он был необоснованно обвинен в организации «контрреволюционной группы» тувинских «троцкистов» и в шпионаже в пользу империалистической Японии (Кара-оол, 2018: 52-53). Бюстом Оюну Танчаю было заложено начало в создании мемориального комплекса жертвам политических репрессий в Туве - «Аллее памяти», которая будет располагаться около здания филиала (г. Кызыл, ул. Комсомольская, д. 5). В будущем он пополнится памятниками шестерым государственным деятелям, расстрелянным в 1938 г., а также тумбами с именами расстрелянных в 1926-1952 гг. граждан Тувы по политическим мотивам.

На сегодняшний день в филиале работает пять человек: заведующий, научный сотрудник, смотритель и два сторожа. Четверо из сотрудников имеют высшее 
образование, из них один учится в аспирантуре и ведет научно-исследовательскую работу по теме политических репрессий в Туве (Доржу, Иргит, 2017; Иргит, 2018).

Таким образом, на примере филиала репрессий, можно выработать следующую стратегию развития других филиалов. На федеральном уровне разрабатываются разные проекты по развитию музейного дела и филиалы тувинского музея также должны участвовать в их реализации, чтобы получить больше возможностей для продвижения своей экспозиции и обмена опыта с коллегами, чтобы выйти на межрегиональный, а затем и на международный уровень сотрудничества.

С помощью филиалов НМ РТ производит музеефикацию ${ }^{1}$ ценностей, которые создаются в наше время. Так, с 2014 г. в местечке Белдир-Кежии Улуг-Хемского района начал создаваться одноименный этнокультурный комплекс с установленными объектами (фото 5-7).

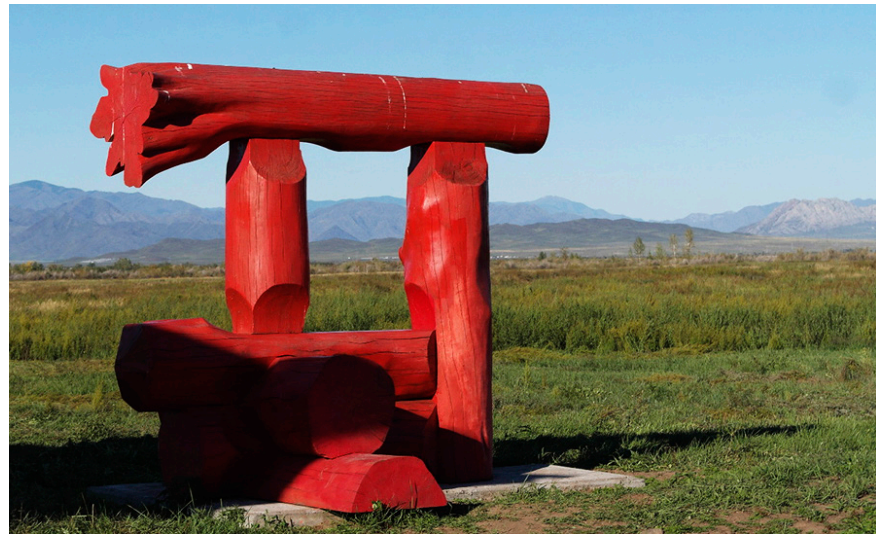

Фото 6. Памятник «Тенгир-Демдее»² на территории филиала НМ РТ «Белдир-Кежии». Фото Х. К. Кадыг-оола, 2016 г.

Photo 6 Tengir Demdee monument at the Beldyr-Kezhii branch of the National museum, Republic of Tuva. Photo by Kh. K. Kadyg-ool, 2016.

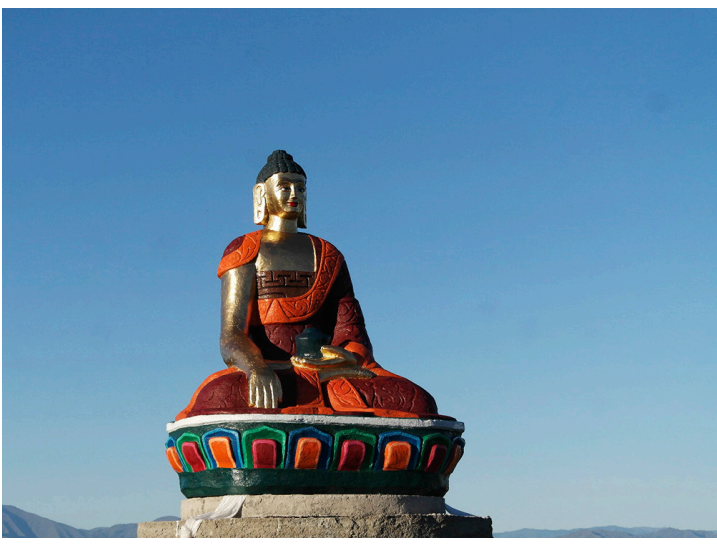

Фото 7. Статуя Будды Шакьямуни на территории филиала НМ РТ «Белдир-Кежии». Фото Х. К. Кадыг-оола, 2016 г. Photo 7 A statue of Shakyamuni Buddha at the Beldyr-Kezhii branch of the National museum, Republic of Tuva. Photo by Kh. K. Kadyg-ool, 2016.

В 2018 г. приказом министра культура Республики Тыва А. К. Тамдына начался процесс создания филиала НМ РТ в виде музея-заповедника. Это означает, что материальные ценности, созданные на этом месте, теперь станут государственной собственностью, что подразумевает соответствующие меры по охране, эксплуатации и т. д. Данный прецедент показывает, что охрана культурного наследия не сходит с актуальной повестки республики. Филиал НМ РТ «Белдир-Кежии» представляет собой пример, как вновь создаваемые культурные ценности входят в поле духовного дискурса, становятся частью мирового наследия. Таким образом, культурное наследие не ограничивается только лишь артефактами прошлого, развитие идет и в наши дни.

В планах НМ РТ также открытие филиала на территории 55 мотострелковой (горной) военной дивизии в г. Кызыле - по просьбе руководства дивизии - постоянной экспозиции о Туве. Таким образом, деятельность филиалов весьма важна в музейном деле Тувы, как минимум, с двух точек зрения: расширение географии и музеефикация современности.

\section{Международное сотрудничество}

Международное сотрудничество НМ РТ сегодня развивается в двух основных направлениях: обмен выставками с зарубежными музеями и предоставление своей площадидля международных мероприятий.

В 2017-2018 гг. НМ РТ реализовал совместный проект с музеем Глауберга (Германия) «Двух миров одно мгновенье». Суть проекта заключалась в том, чтобы выявить общее в двух столь разных культурах.

\footnotetext{
${ }^{1}$ Музеефикация - направление музейной деятельности, заключающееся в преобразовании историко-культурных или природных объектов в музейные объекты с целью максимального сохранения и выявления их историко-культурной, научной, художественной ценности (Каулен, 2012: 13).

${ }^{2}$ Тенгир-Демдее (букв. с тув. «Знак Тенгри») - памятник, который напоминает буквы «Т» и «Д», соответственно. Посвящен древней религии потомков тувинцев - тенгрианству.
} 


\section{НОВЫЕ ИССЛЕДОВАНИЯ ТУВЫ}

www.nit.tuva.asia
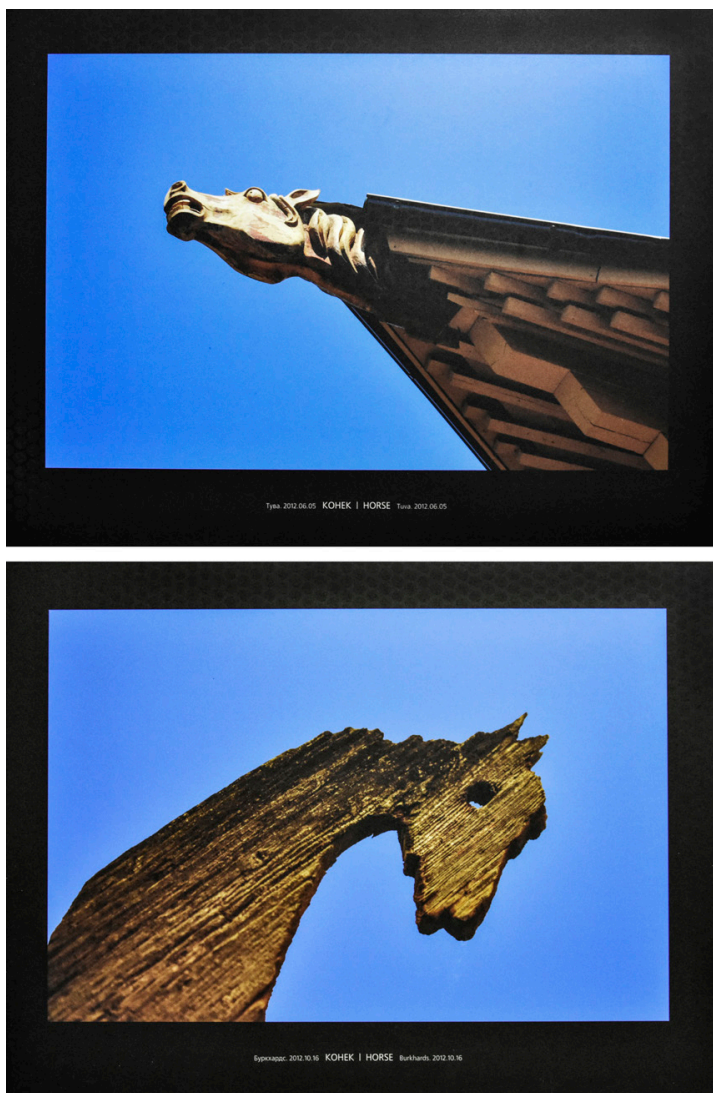

Фото 8. Фрагмент выставки Т. Буркхарда в Национальном музее РТ, 2018 г. Фото А. Д. Куулар. Photo 8 Fragment of a Thomann Burkhard exhibition at the National Museum, Republic of Tuva, 2018. Photo by A. D. Kuular.

И в этом был определенный месседж для всех участников саммита, стран СНГ и Монголии: руководители вооруженных сил своих стран не являются «свирепыми» военачальниками, которые думают только о войнах, согласно общераспространенным стереотипам. Коллекции НМ РТ и творчество С. К. Шойгу продемонстрировали своеобразный культурный актив, который удалось капитализировать в виде успешного, привлекательного, миролюбивого имиджа республики и страны в целом. Данная интерпретация мероприятия вписывается в концепцию т. н. «мягкой силы» (Nye, 2004: 44). Таким образом, международная деятельность НМ РТ выходит за рамки непосредственно культурно-просветительской деятельности, а имеет все возможности для решения и политических задач.
Фотограф Буркхард Томанн, выступая в качестве строительного эксперта, побывал в Туве в 2012 г. Он попытался выразить с помощью фотоснимков определенные параллели между культурами кочевников Центра Азии и кельтов Германии. Экспозиция заключается в том, что на стене в два ряда выставляются фотографии. Верхняя «линия» посвящена Туве, нижняя - Германии. К примеру, дается фотография элемента декора крыши Центра тувинской традиционной культуры и ремесел в виде конской головы и фотография примерно такого же элемента из Германии (фото 8). Расположение снимков призвано побудить зрителя к размышлению над единством смыслов разных культур.

Сначала выставка открылась в Глауберге в 2017 г. В 2018 г. эта выставка открылась в НМ РТ (фото 9).

На 2022 г. между музеями намечается новый проектобмен выставками. Планируется выставить в Кызыле копию знаменитого кельтского князя, а в Германии манекены скифских царя и царицы в полном одеянии с использованием гальванокопий золотых находок из кургана Аржаан II.

Другой вариант международного сотрудничества музей смог реализовать на открытии Саммита министров обороны СНГ и Монголии, который состоялся в г. Кызыле в 6-7 июня 2018 г. Посещение НМ РТ и открытие там персональной выставки Героя России, Генерала Армии, Министра обороны РФ С.К.Шойгу стало первым официальным мероприятием саммита.

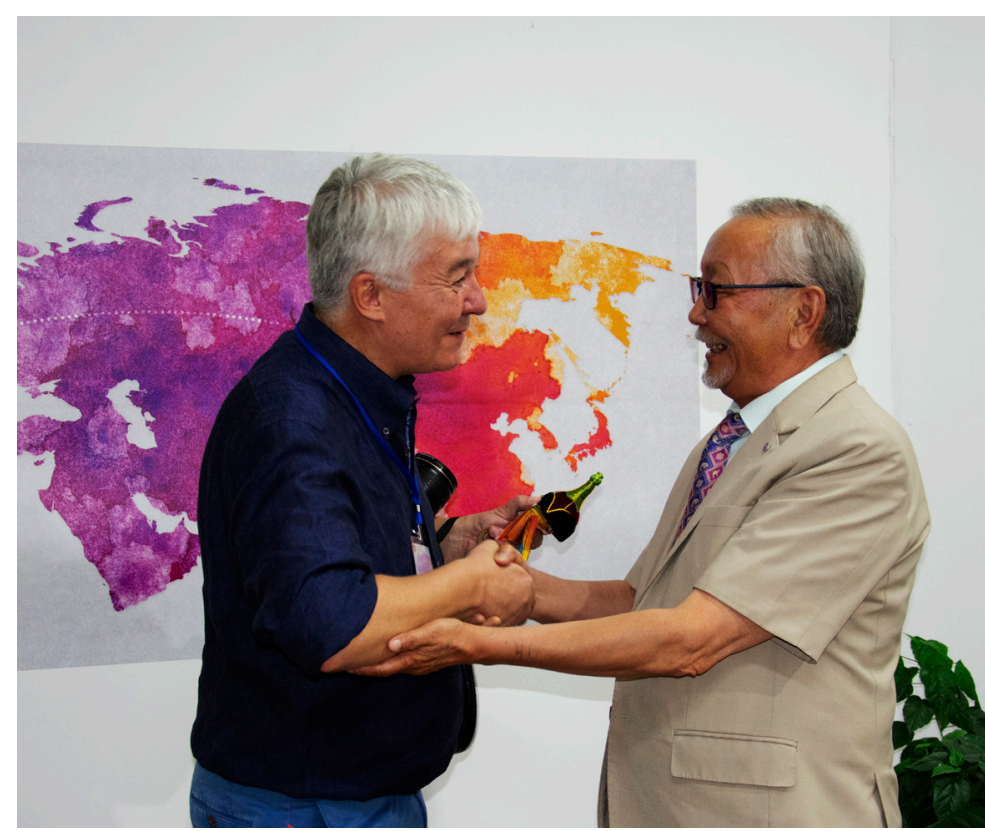

Фото 9. Томанн Буркхард и Каадыр-оол Бичелдей на открытии выставки в г. Кызыле, 2018 г. Фото А. Д. Куулар.

Photo 9 Thomann Burkhard and Kaadyr-ool Bicheldey at the exhibition opening in Kyzyl, 2018 Photo by A. D. Kuular. 


\section{Заключение}

Обзор почти вековой истории развития музейного дела Тувы показал нам богатую историю, в которой музей был и самостоятельной организацией со своими внутренними задачами, и социальным институтом, испытывавшим все перипетии истории республики. Сегодня, очевидно, что музей продолжает быть центром музейного дела всей Тувы, продолжая решать массу разнообразных задач. В их числе и новые задачи, связанные как с быстрыми социальными, культурными изменениями тувинского общества, так и с общими глобализационными тенденциями.

В НМ РТ сегодня, как и на протяжении всей его истории, работают преданные своему делу замечательные специалисты. На смену ветеранам растет новое поколение музейщиков. Постепенно раскрывается научный потенциал музея, его научные сотрудники стремятся к получению ученых степеней, к расширению области практических исследований. Ширятся межрегиональные и международные связи, в связи с этим также можно проследить определенную трансформацию роли музея как хранителя «души» народа - культурного наследия.

Как мы указали в начале статьи, направления развития музеев весьма разнообразные. Для качественного развития необходимо отталкиваться от научной основы - музееведения. Следующий важный шаг - создание профессионального сообщества музейных работников, которое будет включать в себя программистов, ученых, ремесленников и многих других, но именно тех людей, которые решили посвятить себя музею и получили в связи с этим соответствующее профессиональное образование. Для этого НМ РТ должен быть конкурентным работодателем на рынке труда с одной стороны, с другой - привлекать специалистов своими потрясающими коллекциями, возможностью выезжать на всевозможные международные события, строить научную карьеру и т. д. Таким образом, развитие музея должно быть обусловлено не только материальными и финансовыми аспектами.

Музей будет стараться наращивать и, в конце концов, довести свою роль до одного из лидеров в сохранении культурного наследия кочевых народов Центральной Азии. В данном направлении весьма важна научно-популярная, медиа составляющая нашей деятельности. В некотором роде можно даже говорить о своеобразной пропаганде. При качественном планировании развития Национальный музей им. Алдан-Маадыр будет играть все более важную роль в Туве, России и во всем мире музеев, чего мы ему и желаем в связи с юбилеем.

\section{СПИСОК ЛИТЕРАТУРЫ}

Указ Президента Российской Федерации от 07.05.2012 г. № 597 О мероприятиях по реализации государственной социальной политики (2012) [Электронный ресурс] // Президент России. URL: http://kremlin.ru/acts/bank/35261 (дата обращения: 15.02.2019).

Федеральный закон «О Музейном фонде Российской Федерации и музеях в Российской Федерации» от 26.05.1996 N 54-Ф3 (последняя редакция) [Электронный ресурс] // Консультант-Плюс. URL: http://www.consultant.ru/document/ cons_doc_LAW_10496/ (дата обращения: 15.02.2019).

Допай, А. М. (2013) К вопросу о составе шаманской коллекции Национального музея Республики Тыва // Первые республиканские Ермолаевские краеведческие чтения : сборник материалов конференции / отв. за вып. В. С. Чигжит. Кызыл : КЦО «Аныяк». 238 с. С. 119-122.

Доржу, 3. Ю., Иргит, О. Ю. (2017) «Дело Девяти»: судебный процесс 1938 года над государственными деятелями Тувинской Народной Республики в годы политических репрессий // Вестник Калмыцкого университета. № 2 (34). C. 32-39.

Дыртык-оол, А. О. (2009а) Музейное строительство Тувы в составе Российской Федерации. Кызыл : Тув. книжн. изд-во. 136 с.

Дыртык-оол, А. О. (2009b) Основные вехи Национального музея имени Алдан-Маадыр Республики Тыва // Наследие народов Центральной Азии и сопредельных территорий: изучение, сохранение и использование : сборник материалов конференции : в 2 ч. / отв. ред. В. С. Чигжит. Кызыл : КЦО «Аныяк». Ч. 1. 198 с. С. 9-17.

Дыртык-оол, А. О. (2013) Владимир Петрович Ермолаев - первый директор Тувинского музея // Первые республиканские Ермолаевские краеведческие чтения : сборник материалов конференции / отв. за вып. В. С. Чигжит. Кызыл : КЦО «Аныяк». 238 с. С. 11-14.

Дыртык-оол, А. О. (2014) Экспозиционно-выставочная работа в музее. Кызыл : КцО «Аныяк». 68 с.

Дыртык-оол, А. О., Мартынов, А. И. (2019) Выставочная деятельность Национального музея Республики Тыва (1990-2018 гг.) [Электронный ресурс] // Новые исследования Тувы. № 2. URL: https://nit.tuva.asia/nit/article/view/842 DOI: $10.25178 /$ nit.2019.2.2

Иргит, О. Ю. (2018) Первая волна политических репрессий в Туве (1923-1933) // Проблемы социально-экономического развития Сибири. № 1 (31). С. 94-99. 
История музея [Электронный ресурс] // Национальный музей имени А. В. Анохина. URL: http://www.musey-anohina.ru/index.php/o-muzee/istoriya-muzeya (дата обращения: 20.02.2019).

Кара-оол, В. Х. (2018) Оюн Танчайнын орук-чолу [Судьба Оюна Танчая]. Кызыл : Тув. книжн. изд-во. 240 с. (На тув. языке).

Каулен, М. Е. (2012) Музеефикация историко-культурного наследия России. М. : Этерна. 432 с.

Кенин-Лопсан, М. Б. (1987) Обрядовая практика и фольклор тувинского шаманства. Конец XIX - начало XX в. Новосибирск : Наука. 162 с.

Кенин-Лопсан, М. Б. (2006) Традиционная культура тувинцев. Кызыл : Тув. кн. изд-во. 232 с.

Кенин-Лопсан, М. Б. (2007) Алгыши тувинских шаманов / пер. авт. с тув. М. Б. Кенин-Лопсан. Якутск : Бичик. 206 с.

Кенин-Лопсан, М. Б. (2008) Дыхание черного неба : мифологическое наследие тувинского шаманства. Москва : Велигор. 180 с.

Кенин-Лопсан, М. Б. (2009) Шаманское зеркало с когтем медведя // Наследие народов Центральной Азии и сопредельных территорий: изучение, сохранение и использование : сборник материалов конференции : в 2 ч. / отв. ред. В. С. Чигжит. Кызыл : КЦО «Аныяк». Ч. 1.198 с. С. 29-34.

Кенин-Лопсан, М.Б. (2013) Владимир Петрович Ермолаев - знаменитый краевед Тувы // Первые республиканские Ермолаевские краеведческие чтения : сборник материалов конференции / отв. за вып. В. С. Чигжит. Кызыл : КЦО «Аныяк». 238 с. С. $7-11$.

Концепция государственной политики по увековечению памяти жертв политических репрессий [Электронный ресурс] // Совет при Президенте Российской Федерации по развитию гражданского общества и правам человека. URL: http://www.president-sovet.ru/files/73/3d/733de2e296875c3538917ea679fa02d1.pdf (дата обращения: 21.11.2018).

Круглый стол «Дело девяти: особенности политических репрессий в Туве» (2018) [Электронный ресурс] // Национальный музей Республики Тыва им. «Алдан-Маадыр». 17 апреля. URL: http://museum.tuva.ru/?p=3265 (дата обращения: 15.02.2019).

Музейное дело [Электронный ресурс] // Российская музейная энциклопедия. URL: http://www.museum.ru/rme/dictionary.asp?98 (дата обращения: 20.02.2019).

Музейное дело России (2003) / под ред. М. Е. Каулен (отв. ред.), И. М. Коссовой, А. А. Сундиевой. М. : Изд-во «ВК». $614 \mathrm{c}$.

Наследие народов Центральной Азии и сопредельных территорий: изучение, сохранение и использование : сборник материалов конференции (2009) : в 2 ч. / отв. ред. В. С. Чигжит. Кызыл : КЦО «Аныяк». 198 + 223 с.

Нурзат, У. Б. (2013) Тувинские этнографические коллекции Национального музея Республики Тыва: состав и степень изученности // Первые республиканские Ермолаевские краеведческие чтения : сборник материалов конференции (2013) / отв. за вып. В. С. Чигжит. Кызыл : КЦО «Аныяк». 238 с. С. 114-119.

Об Ассоциации [Электронный ресурс] // Сайт Ассоциации российских музеев памяти. URL: http://memorymuseums.ru/\#about (дата обращения: 21.11.2018).

Проект БЕЪЛДИР-КЕЪЖИИ [Электронный ресурс] // ТРОО «Мир тувинцев». URL: https://mirtuvintsev.ru/?page $\mathrm{id}=149$ (дата обращения: 20.02.2019).

Стаф, В. С. (2018) Мемориализация «негативного наследия» в современной России на материале лагерных музеев в Пермском крае // Вестник Томского государственного университета. № 428. С. 183-187.

Сумба, Р.П.(2013) Описание тувинских семейных обрядов, связанных с детьми, в «шаманских текстах» из собрания тибетских рукописей и ксилографов в фондах Национального музея Республики Тыва // Первые республиканские Ермолаевские краеведческие чтения : сборник материалов конференции (2013) / отв. за вып. В. С. Чигжит. Кызыл : КЦО «Аныяк». 238 с. С. 107-114.

Тока, С. К. (1973) Слово арата. М. : Современник. 432 с.

Хакасский национальный краеведческий музей им. Л. Р. Кызласова [Электронный ресурс] // Хакасский национальный краеведческий музей им. Л. Р. Кызласова. URL: http://www.nhkm.ru/index.php?option=com_content \&view=art icle\&id=24\&Itemid=200\&lang=ru (дата обращения: 20.02.2019).

Хертек, А. С. От народного к профессиональному : (традиции и преемственность) в изобразительном искусстве Республики Тува // Культура Тувы : прошлое и настоящее : сб. материалов науч.-практ. конф., (г. Кызыл, 3 марта, 31 марта 2004 г.) / ред.-сост. И. В. Подик. Кемерово : Изд. КемГУКИ. Вып. 1. 223 с. С. 28-33.

Ховалыг, Р. Б. (2013) Проблемы реставрации и консервации музейных предметов в Национальном музее Республики Тыва // Проблемы сохранения, изучения и использования культурного наследия в современном музее : сб. статей межрег. науч.-практ. конф., посвящ. 90-летию Музея истории Бурятии им. М. Н. Хангалова и 155-летию со дня рожд. выдающ. этногр. М. Н. Хангалова, 21-25 окт. 2013 г. / редкол. : Т. А. Боронаева [и др.]. Улан-Удэ : Изд-во БГСХА им. В. Р. Филиппова. 259 с. С. 118-123.

Чжуан-Цзы. Чжуан-Цзы // Философское наследие : в 138 т. / вступ. ст. и примеч. В. В. Малявина. М. : Мысль. Т. 123. 440 c. C. $58-284$. 
Alexander, P. E., Alexander M. (2008) Museums in Motion: An Introduction to the History and Functions of Museums. $2^{\text {nd }}$ ed. Lanham : AltaMira Press. 352 p.

Hagen, H. A. (1876) The History of the Origin and Development of Museums // The American Naturalist. Vol. 10, No. 2. P. $80-89$. DOI: $10.1086 / 271587$

Mairesse, F. (2015) New trends in museology // ICOFOM Study Series. 43b. P. 15-17.

Nye, S. J. (2004) Soft power. The means to success in world politics. New-York: Public Affairs. 192 p.

Silent disco [Электронный ресурс] // Natural History Museum. URL: http://www.nhm.ac.uk/events/silent-disco.html (дата обращения: 20.02.2019).

Дата поступления: 01.03.2019 2.

\section{REFERENCES}

Ukaz Prezidenta Rossiiskoi Federatsii ot 07.05.2012 g. № 597 O meropriiatiiakh po realizatsii gosudarstvennoi sotsial'noi politiki [Decree of the President of the Russian Federation No. 597 of 07.05.2012 On measures of implementing the state social policy] (2012). Prezident Rossii [online] Available at: http://kremlin.ru/acts/bank/35261 (access date: 15.02.2019). (In Russ.).

Federal'nyi zakon «O Muzeinom fonde Rossiiskoi Federatsii i muzeiakh v Rossiiskoi Federatsii» ot 26.05.1996 N 54-FZ (posledniaia redaktsiia) [Federal law "On the Museum Fund of the Russian Federation and museums in the Russian Federation” of 26.05.1996 N 54-FZ (latest edition)]. Konsul'tant-Plius [online] Available at: http://www.consultant.ru/document/ cons_doc_LAW_10496/(access date: 15.02.2019). (In Russ.).

Dopai, A. M. (2013) K voprosu o sostave shamanskoi kollektsii Natsional'nogo muzeia Respubliki Tyva [On the issue of the shamanic part of the collection of the National Museum of Tuva Republic]. In: Pervye respublikanskie Yermolayevskie kraevedcheskie chteniia [1st Yermolayev readings in local history, Republic of Tuva]: conference proceedings / ed. by V. S. Chigzhit. Kyzyl, KTsO «Anyiak». 238 p. Pp. 119-122. (In Russ.).

Dorzhu, Z. Yu. and Irgit, O. Iu. (2017) «Delo Deviati»: sudebnyi protsess 1938 goda nad gosudarstvennymi deiateliami Tuvinskoi Narodnoi Respubliki v gody politicheskikh repressii ["The case of the Nine": the 1938 trial of the statesmen of the People's Republic of Tuva during the years of political repressions]. Vestnik Kalmytskogo universiteta, no. 2 (34), pp. 32-39. (In Russ.).

Dyrtyk-ool, A. O. (2009a) Muzeinoe stroitel'stvo Tuvy v sostave Rossiiskoi Federatsii [Museum-building of Tuva as a subject of the Russian Federation]. Kyzyl, Tuva book publishing house. 136 p. (In Russ.).

Dyrtyk-ool, A. O. (2009b) Osnovnye vekhi Natsional'nogo muzeia imeni Aldan-Maadyr Respubliki Tyva [Major milestones in the history of the Aldan-Maadyr National Museum, Republic of Tuva]. In: Nasledie narodov Tsentral'noi Azii i sopredel'nykh territorii: izuchenie, sokhranenie i ispol'zovanie [Heritage of the peoples of Central Asia and adjacent territories: study, conservation and use] : proceedings of the conference : in 2 parts / ed. by V. S. Chigzhit. Kyzyl, KTsO «Anyiak». Part 1198 p. Pp. 9-17. (In Russ.).

Dyrtyk-ool, A. O. (2013) Vladimir Petrovich Yermolayev - pervyi direktor Tuvinskogo muzeia [Vladimir Petrovich Yermolayev, the first director of the Museum of Tuva]. In: Pervye respublikanskie Yermolayevskie kraevedcheskie chteniia [1st Yermolayev readings in local history, Republic of Tuva] : conference proceedings / ed. by V. S. Chigzhit. Kyzyl, KTsO «Anyiak». 238 p. Pp. 11-14. (In Russ.).

Dyrtyk-ool, A. O. (2014) Ekspozitsionno-vystavochnaia rabota v muzee [Exhibition work at the Museum]. Kyzyl, KTsO «Anyiak». 68 p. (In Russ.).

Dyrtyk-ool, A. O. and Martynov, A. I. (2019) Vystavochnaia deiatel'nost' Natsional'nogo muzeia Respubliki Tyva (19902018 gg.). [Exhibition work at the National Museum, Republic of Tuva, 1990-2018]. The New Research of Tuva, no. 2 [online] Available at: https://nit.tuva.asia/nit/article/view/842 (In Russ.). DOI: 10.25178/nit.2019.2.2

Irgit, O. Iu. (2018) Pervaia volna politicheskikh repressii v Tuve (1923-1933) [The first wave of political repressions in Tuva (1923-1933)]. Problemy sotsial'no-ekonomicheskogo razvitiia Sibiri, no. 1 (31), pp. 94-99. (In Russ.).

Istoriia muzeia [History of the Museum]. Natsional'nyi muzei imeni A. V. Anokhina [online] Available at: http://www. musey-anohina.ru/index.php/o-muzee/istoriya-muzeya (access date: 20.02.2019). (In Russ.).

Kara-ool, V. Kh. (2018) Oiun Tanchainyn oruk-cholu [The fate of Oyun Tanchay]. Kyzyl, Tuva book publishing house. 240 p. (In Tuv.).

Kaulen, M. E. (2012) Muzeefikatsiia istoriko-kul'turnogo naslediia Rossii [Museumification of historical and cultural heritage in Russia]. Moscow, Eterna. 432 p. (In Russ.).

Kenin-Lopsan, M. B. (1987) Obriadovaia praktika i fol'klor tuvinskogo shamanstva. Konets XIX - nachalo XX v. [Ritual practices and folklore of Tuvan shamanism: late 19th - early 20th century]. Novosibirsk, Nauka. 162 p. (In Russ.).

Kenin-Lopsan, M. B. (2006) Traditsionnaia kul'tura tuvintsev [Traditional culture of Tuvans]. Kyzyl, Tuva book publishing house. 232 p. (In Russ.).

Kenin-Lopsan, M. B. (2007) Algyshi tuvinskikh shamanov [Algyshy of Tuvan shamans] / transl. from Tuv. by M. B. KeninLopsan. Iakutsk, Bichik. 206 p. (In Russ.). 
НОВЫЕ ИССЛЕДОВАНИЯ ТУВЫ

www.nit.tuva.asia

Kenin-Lopsan, M. B. (2008) Dykhanie chernogo neba: mifologicheskoe nasledie tuvinskogo shamanstva [Breath of the black sky: mythological heritage of Tuvan shamanism]. Moscow, Veligor. 180 p. (In Russ.).

Kenin-Lopsan, M. B. (2009) Shamanskoe zerkalo s kogtem medvedia [A Shamanic mirror with a bear's claw]. In: Nasledie narodov Tsentral'noi Azii i sopredel'nykh territorii: izuchenie, sokhranenie i ispol'zovanie [Heritage of the peoples of Central Asia and adjacent territories: study, conservation and use] : proceedings of the conference : in 2 parts / ed. by V. S. Chigzhit. Kyzyl, KTsO «Anyiak». Part 1198 p. Pp. 29-34. (In Russ.)

Kenin-Lopsan, M. B. (2013) Vladimir Petrovich Yermolayev - znamenityi kraeved Tuvy [Vladimir Petrovich Yermolayev, prominent local historian of Tuva]. In: Pervye respublikanskie Yermolayevskie kraevedcheskie chteniia [1st Yermolayev readings in local history, Republic of Tuva] : conference proceedings / ed. by V. S. Chigzhit. Kyzyl, KTsO «Anyiak». 238 p. Pp. 7-11. (In Russ.).

Kontseptsiia gosudarstvennoi politiki po uvekovecheniiu pamiati zhertv politicheskikh repressii [The concept of state policy to perpetuate the memory of victims of political repression]. Sovet pri Prezidente Rossiiskoi Federatsii po razvitiiu grazhdanskogo obshchestva i pravam cheloveka [online] Available at: http://www.president-sovet.ru/files/73/3d/733de2e29 6875c3538917ea679fa02d1.pdf (access date: 21.11.2018). (In Russ.).

Kruglyi stol «Delo deviati: osobennosti politicheskikh repressii v Tuve» [Round table "The case of the Nine: features of political repression in Tuva”] (2018). Natsional'nyi muzei Respubliki Tyva im. Aldan-Maadyr, 17 April [online] Available at: http://museum.tuva.ru/?p=3265 (access date: 15.02.2019). (In Russ.).

Muzeinoe delo [Museum business]. Rossiiskaia muzeinaia entsiklopediia [online] Available at: http://www.museum.ru/ rme/dictionary.asp?98 (access date: 20.02.2019). (In Russ.).

Muzeinoe delo Rossii [Museums business of Russia] (2003) / ed. by M. E. Kaulen, I. M. Kossova and A. A. Sundieva. Moscow, VK Publ. 614 p. (In Russ.).

Nasledie narodov Tsentral'noi Azii i sopredel'nykh territorii: izuchenie, sokhranenie i ispol'zovanie [Heritage of the peoples of Central Asia and adjacent territories: study, conservation and use]: conference proceedings: in 2 parts / ed. by V. S. Chigzhit. Kyzyl, KTsO «Anyiak». $198+223$ p. (In Russ.).

Nurzat, U. B. (2013) Tuvinskie etnograficheskie kollektsii Natsional'nogo muzeia Respubliki Tyva: sostav i stepen' izuchennosti [Tuvan ethnographic collections of the National Museum of the Republic of Tyva: composition and depth of study]. In: Pervye respublikanskie Yermolayevskie kraevedcheskie chteniia [1st Yermolayev readings in local history, Republic of Tuva] : conference proceedings / ed. by V. S. Chigzhit. Kyzyl, KTsO «Anyiak». 238 p. Pp. 114-119. (In Russ.).

Ob Assotsiatsii [About the Association]. Sait Assotsiatsii rossiiskikh muzeev pamiati [online] Available at: http://memorymuseums.ru/\#about (access date: 21.11.2018). (In Russ.).

Proekt BELDIR-KEZHYY [Project BELDIR-KEZHYY]. TROO «Mir tuvintsev» [online] Available at: https://mirtuvintsev. ru/?page_id=149 (access date: 20.02.2019). (In Russ.).

Staf, V. S. (2018) Memorializatsiia «negativnogo naslediia» v sovremennoi Rossii na materiale lagernykh muzeev v Permskom krae ["Negative heritage" memorialization in contemporary Russia: the case of camp museums in Perm Krai]. Vestnik Tomskogo gosudarstvennogo universiteta, no. 428, pp. 183-187. (In Russ.).

Sumba, R. P. (2013) Opisanie tuvinskikh semeinykh obriadov, sviazannykh s det'mi, v «shamanskikh tekstakh» iz sobraniia tibetskikh rukopisei i ksilografov v fondakh Natsional'nogo muzeia Respubliki Tyva [A description of Tuvan family rites related to children in the "shamanic texts" from the collection of Tibetan manuscripts and woodcuts in the collections of the National Museum, Republic of Tuva]. In: Pervye respublikanskie Yermolayevskie kraevedcheskie chteniia [1st Yermolayev readings in local history, Republic of Tuva] : conference proceedings / ed. by V. S. Chigzhit. Kyzyl, KTsO «Anyiak». 238 p. Pp. 107-114. (In Russ.).

Toka, S. K. (1973) Slovo arata [The word of an Arat]. Moscow, Sovremennik. 432 p. (In Russ.).

Khakasskii natsional'nyi kraevedcheskii muzei im. L. R. Kyzlasova [L.R. Kyzlasov Khakass National Museum]. Khakasskii natsional'nyi kraevedcheskii muzei im. L. R. Kyzlasova [online] Available at: http://www.nhkm.ru/index.php?option=com_co ntent\&view=article\&id=24\&Itemid=200\&lang=ru (access date: 20.02.2019). (In Russ.).

Khertek, A. S. Ot narodnogo k professional'nomu : (traditsii i preemstvennost') v izobrazitel'nom iskusstve Respubliki Tuva [From folk to professional art: traditions and continuity in the fine arts of the Republic of Tuva]. In: Kul'tura Tuvy : proshloe i nastoiashchee [Culture of Tuva : past and present] : conference proceedings. (Kyzyl, March 3, 2004) / ed.: I. V. Podik. Kemerovo, KemGUKI Publ. Vol. 1223 p. Pp. 28-33. (In Russ.).

Khovalyg, R. B. (2013) Problemy restavratsii i konservatsii muzeinykh predmetov v Natsional'nom muzee Respubliki Tyva [Issues of restoration and conservation of museum objects in the National Museum, Republic of Tyva]. In: Problemy sokhraneniia, izucheniia $i$ ispol'zovaniia kul'turnogo naslediia $v$ sovremennom muzee [Problems of preservation, study and use of cultural heritage in the modern museum] : proceeding of the conference on 90th anniversary of the Khangalov Museum of Buryatia and the 155th anniversary of M. N. Angelov, 21-25 Oct. 2013 / eds.: Borodaeva T. A. et al. Ulan-Ude, BGSKhA Publ. 259 p. Pp. 118-123. (In Russ.).

Zhuang Zhou. Zhuangzi. In: Filosofskoe nasledie [Philosophical heritage]: in 138 vol. / introductory article and notes by V. V. Maliavin. Moscow, Mysl'. Vol. 123440 p. Pp. 58-284. (In Russ.). 
Alexander, P. E. and Alexander M. (2008) Museums in Motion: An Introduction to the History and Functions of Museums. 2nd ed. Lanham, AltaMira Press. 352 p.

Hagen, H. A. (1876) The History of the Origin and Development of Museums. The American Naturalist, vol. 10, no. 2, pp. 80-89. DOI: $10.1086 / 271587$

Mairesse, F. (2015) New trends in museology. ICOFOM Study, Series 43b, pp. 15-17.

Nye, S. J. (2004) Soft power. The means to success in world politics. New-York, Public Affairs. 192 p.

Silent disco. Natural History Museum [online] Available at: http://www.nhm.ac.uk/events/silent-disco.html (access date: 20.02.2019).

Submission date: 01.03.2019. 